\title{
Carotenoids and risk of fracture: a meta-analysis of observational studies
}

\author{
Jiuhong $\mathrm{Xu}^{1, *}$, Chunli Song ${ }^{2, *}$, Xiaochao Song ${ }^{2}, \mathrm{Xi} \mathrm{Zhang}^{3}$, Xinli Li ${ }^{2,4}$ \\ ${ }^{1}$ Department of Radiotherapy, The First Affiliated Hospital of Soochow University, Suzhou Jiangsu, PR China, 215006 \\ ${ }^{2}$ School of Public Health, Medical College of Soochow University, Suzhou, Jiangsu, PR China, 215123 \\ ${ }^{3}$ Clinical Research Unit, Xinhua Hospital Affiliated to Shanghai Jiaotong University School of Medicine, Shanghai, PR China, \\ 200092 \\ ${ }^{4}$ Jiangsu Key Laboratory of Preventive and Translational Medicine for Geriatric Diseases, School of Public Health, Soochow \\ University, Suzhou, PR China, 215123 \\ *These authors contributed equally to this work
}

Correspondence to: Xinli Li, email: lixinli@suda.edu.cn

Keywords: carotenoids, carotene, lycopene, $\beta$-cryptoxanthin, lutein/zeaxanthin

Received: July 02, $2016 \quad$ Accepted: November 22, $2016 \quad$ Published: November 29, 2016

\section{ABSTRACT}

To quantify the association between dietary and circulating carotenoids and fracture risk, a meta-analysis was conducted by searching MEDLINE and EMBASE databases for eligible articles published before May 2016. Five prospective and 2 case-control studies with 140,265 participants and 4,324 cases were identified in our meta-analysis. Among which 5 studies assessed the association between dietary carotenoids levels and hip fracture risk, 2 studies focused on the association between circulating carotenoids levels and any fracture risk. A random-effects model was employed to summarize the risk estimations and their $95 \%$ confidence intervals (CIs). Hip fracture risk among participants with high dietary total carotenoids intake was 28\% lower than that in participants with low dietary total carotenoids (OR: 0.72; $95 \%$ CI: $0.51,1.01)$. A similar risk of hip fracture was found for $\beta$-carotene based on 5 studies, the summarized OR for high vs. low dietary $\beta$-carotene was 0.72 (95\% CI: $0.54,0.95)$. However, a significant between-study heterogeneity was found (total carotene: $\mathrm{I}^{2}=59.4 \%, P=0.06 ; \beta$-carotene: $\left.\mathrm{I}^{2}=74.4 \%, P=0.04\right)$. Other individual carotenoids did not show significant associations with hip fracture risk. Circulating carotene levels had no significant association with any fracture risk, the pooled OR ( $95 \% \mathrm{CI})$ was $0.83(0.59,1.17)$. Based on the evidence from observational studies, our meta-analysis supported the hypothesis that higher dietary total carotenoids or $\beta$-carotene intake might be potentially associated with a low risk of hip fracture, however, future well-designed prospective cohort studies and randomized controlled trials are warranted to specify the associations between carotenoids and fracture.

\section{INTRODUCTION}

Osteoporosis, characterized by obvious bone loss and micro-architectural disruption, results in bone fragility and an increased susceptibility to fractures [1]. Elderly population, especially older women, are at higher risk of osteoporosis, as aging could facilitate the decrease of bone mass [2]. With the increase of the ratio of elderly people, osteoporosis and osteoporotic fracture is now regarded to be an age-related serious public health problem worldwide.
Experimental research has highlighted the involvement of reactive oxygen species (ROS) and free radicals in inducing bone loss by regulating osteoclastogenesis [3] and osteoclastic differentiation [4], apoptosis of osteoblasts and osteocytes [5], and decreasing osteoblastic differentiation [6]. Epidemiological studies also suggested a negative association between oxidative stress and BMD (Bone Mineral Density) [7-9], or risk of osteoporosis, which is further supported by the evidence of elevated serum oxidative stress marker in osteoporosis 
patients [10]. Thus, it is reasonable to make a hypothesis that inhibition of oxidative stress might be useful to counteract the decrease of BMD, slow down the process of osteoporosis, and reduce the risk of osteoporotic fractures.

Dietary antioxidant carotenoids, enriched in vegetables and fruits, have been testified to protect the human body's defense against the reactive oxygen species [11]. Carotenoids mainly include $\beta$-carotene, $\alpha$-carotene, $\beta$-cryptoxanthin, lutein, zeaxanthin, and lycopene, which account for $\sim 70 \%$ of all carotenoids. Those individual carotenoids had different chemical formula, molecular mass and structure, antioxidant ability, and also conserve different ability to convert into Vitamin A. Although the results from animal studies suggested that lycopene $[12,13]$ and $\beta$-cryptoxanthin [14] could reduce the risk of osteoporosis and related fractures, epidemiological studies have drawn inconsistent conclusions. Several studies, including the Framingham Osteoporosis Study [15] and the Utah Study of Nutrition and Bone Health [16], reported that high intake or high serum levels of carotenoids was associated with decreased risk of osteoporosis and fracture [10, 17-24], while other researches deduced conflicting results, Barker et al. found a non-significant association between serum $\beta$-carotene and hip fracture risk among elderly women [25], Framingham Osteoporosis Study also showed a null association of dietary lycopene with hip fracture risk among women [15].

Thus, our present work aimed to conduct a quantitative meta-analysis by summarizing the evidence from current observational studies to comprehensively clarify the associations between carotenoids and fractures risk.

\section{RESULTS}

\section{Literature collection}

We identified 374 articles from the MEDLINE database and 473 from EMBASE database. After excluding the review papers, papers without reporting risk estimates, papers with irrelevant exposure factors (mainly related to Vitamin A, retinol or dietary pattern), papers with irrelevant endpoints (mainly about BMD or bone turnover), or basic experimental research by title/ abstract screening, a total of 64 articles were selected for full-text review. We finally identified 7 studies by using full-text screening, including 5 prospective $[15,22,23$, $25,26]$ and 2 case-control studies [16, 27]. Five studies $[15,16,23,26,27]$ assessed the association between dietary carotenoids levels and hip fracture risk and 2 studies [22, 25] focused on the association between circulating carotenoids levels and risk of any fracture. The detailed process for study section is presented in Figure 1.

\section{Characteristics of the included studies}

The characteristics of all 7 selected studies are displayed in Table 1. These studies were published between 2002 and 2014, with a total of 140,265 participants and 4,324 fracture cases. All participants of these studies aged $\geq 50$ years (range: $50-80$ years) and their mean BMI ranged from 21.5 to $27.4 \mathrm{~kg} / \mathrm{m}^{2}$. Nearly $80 \%(111,336 / 140,265)$ of studies participants were women and all women were post-menopausal. Two studies were conducted among Asian population [23, 27], 3 studies were conducted among Americans $[15,16,26]$, and 2 studies were in Oceania [22] and Europe [25], respectively. The follow-up duration of prospective studies ranged from 3.7 years to 18 years. Dietary carotenoids intake was assessed by validated food frequency questionnaires (FFQ), and circulating carotenoids concentrations were determined by the highperformance liquid chromatography (HPLC). All fracture cases were ascertained by surgical records or medical records except Ambrosini's study [22], in which fracture cases were self-reported. The variables adjusted in the regression models mainly included age, BMI, education, total energy intake, smoking status, physical activity, intakes of calcium, soy isoflavones and vitamin B6, menopausal status, use of hormone replacement therapy, and history of diabetes and stroke.

\section{Dietary total or individual carotenoids and hip fracture risk}

Of all 7 identified studies, 5 studies focused on the association between dietary carotenoids and hip fracture risk, among which 2 studies focused on the dietary total carotenids . Compared to the participants with low carotenoids intake, the OR of hip fracture risk among participants with high total carotenoids intake was 0.72 (95\% CI: $0.51,1.01 ; \mathrm{I}^{2}=59.4 \%, P=0.06$ ) (Figure 2).

Five studies explored the relationship between dietary individual carotenoids, such as $\alpha-, \beta$-carotene, $\beta$-cryptoxanthin, lycopene, and Lutein/zeaxanthin, and hip fracture risk. As shown in Figure 3, high intake of dietary $\beta$-carotene significantly decreased the risk of hip fracture, and the OR was 0.72 ( $95 \%$ CI: $0.54,0.95)$, while other individual carotenoids did not show any significant associations with hip fracture risk, the pooled OR was 0.77 (95\% CI: $0.55,1.08)$ for $\alpha$-carotene, 1.11 (95\% CI: $0.97,1.28)$ for $\beta$-cryptoxanthin, 0.84 (95\% CI: $0.69,1.01)$ for lycopene, and 0.94 (95\% CI: $0.79,1.11)$ for Lutein/zeaxanthin, respectively. Significant heterogeneities were found in the meta-analyses of $\alpha$-carotene $\left(\mathrm{I}^{2}=63.8 \%, P<0.001\right)$ and $\beta$-carotene $\left(\mathrm{I}^{2}=74.4 \%, P=0.04\right)$, respectively.

Further subgroup analysis showed that dietary $\beta$-carotene decreased hip fracture risk among men 
Table 1: Characteristics of selected studies in the meta-analysis

\begin{tabular}{|c|c|c|c|c|c|c|c|}
\hline $\begin{array}{l}\text { Author }{ }^{(\mathrm{ref}) /} \\
\text { year/location }\end{array}$ & $\begin{array}{l}\text { Study } \\
\text { Design/ } \\
\text { Duration }\end{array}$ & $\begin{array}{l}\text { Case/participants/ } \\
\text { female, } \% / \text { age/ } \\
\text { BMI, } \mathbf{k g} / \mathbf{m}^{2}\end{array}$ & $\begin{array}{l}\text { Source/special } \\
\text { CA }\end{array}$ & $\begin{array}{l}\text { CA assessment/ } \\
\text { compared groups }\end{array}$ & $\begin{array}{l}\text { Research } \\
\text { endpoint/Case } \\
\text { ascertainment }\end{array}$ & Adjusted variables & $\begin{array}{l}\text { Quality } \\
\text { Score }\end{array}$ \\
\hline $\begin{array}{l}\mathrm{Dai}^{(23)} \\
/ 2014 \\
\text { /Singapore }\end{array}$ & $\begin{array}{l}\text { Cohort } \\
/ 9.9 \mathrm{y}\end{array}$ & $\begin{array}{l}\text { 1630/61524/ } \\
55.8 \% / 56.3 y / m e n: \\
23 ; \text { women: } 23.2\end{array}$ & $\begin{array}{l}\text { Diet/total CA; } \\
\alpha-, \beta \text { - carotene, } \\
\text { lycopene, } \\
\beta \text {-cryptoxanthin, } \\
\text { lutein/zeaxanthin }\end{array}$ & $\begin{array}{l}\mathrm{FFQ} / \alpha \text {-carotene: } \\
\mathrm{Q} 1<59.8 ; \mathrm{Q} 4> \\
212.3 ; \beta \text {-carotene: } \\
\mathrm{Q} 1<850.4 ; \mathrm{Q} 4 \\
>1772.4 ; \text { lutein/ } \\
\text { zeaxanthin:Q1< } \\
\text { 781.8; Q4 > } 1544.1 ; \\
\text { Lycopene: Q1 }< \\
\text { 191.9; Q4 > 858.4 }\end{array}$ & $\begin{array}{l}\text { Hip fracture } \\
\text { /Surgical or } \\
\text { medical records }\end{array}$ & $\begin{array}{l}\text { Age, recruitment year, dialect } \\
\text { group, BMI, education, total } \\
\text { energy intake, smoking, } \\
\text { physical activity, calcium, } \\
\text { vitamin B6, soy isoflavones, } \\
\text { menopausal status, history } \\
\text { of diabetes and stroke, use } \\
\text { of HRT. }\end{array}$ & 8 \\
\hline $\begin{array}{l}\text { Sahni(15) } \\
/ 2009 \\
\text { /US }\end{array}$ & $\begin{array}{l}\text { Cohort } \\
/ 17 \mathrm{y}\end{array}$ & $\begin{array}{l}100 / 946 / 61 \% \\
175 y / 25.5\end{array}$ & $\begin{array}{l}\text { Diet/total CA; } \\
\alpha-, \beta \text { - carotene, } \\
\text { lycopene, } \\
\beta \text {-cryptoxanthin, } \\
\text { lutein/zeaxanthin }\end{array}$ & $\begin{array}{l}\text { FFQ/carotenoids; } \\
\text { T1: 7299; T3:23711 } \\
\text { Lycopene: } \\
\text { T1:2710; T3:12664 }\end{array}$ & $\begin{array}{l}\text { Hip fracture } \\
\text { /Medical records, } \\
\text { radiographic and } \\
\text { operative reports }\end{array}$ & $\begin{array}{l}\text { Sex, age, BMI, height, } \\
\text { energy intake, physical } \\
\text { activity, alcohol intake, } \\
\text { smoking, calcium intake, } \\
\text { vitamin D intake, caffeine } \\
\text { intake }\end{array}$ & 8 \\
\hline $\begin{array}{l}\text { Feskanich }^{(26)} \\
\text { /2002 } \\
\text { /US }\end{array}$ & $\begin{array}{l}\text { Cohort } \\
/ 18 \mathrm{y}\end{array}$ & $\begin{array}{l}603 / 72337 / 100 \% \\
/ 59.6 \mathrm{y} / 26\end{array}$ & $\begin{array}{l}\text { Diet } \\
/ \beta \text {-carotene }\end{array}$ & $\begin{array}{l}\mathrm{FFQ} / \beta \text {-carotene Q1: } \\
<2550 ; \mathrm{Q} 5: \geq 6300\end{array}$ & $\begin{array}{l}\text { Hip fracture } \\
\text { /Self-report, and } \\
\text { medical record } \\
\text { confirmed }\end{array}$ & $\begin{array}{l}\text { Age, follow-up cycle, BMI, } \\
\text { HRT, smoking, physical } \\
\text { activity, use of thiazide } \\
\text { diuretics, intake of calcium, } \\
\text { protein, Vitamin D, Vitamin } \\
\text { K, alcohol, caffeine. }\end{array}$ & 8 \\
\hline $\begin{array}{l}\text { Sun } \\
\text { /2014 } \\
\text { /China }\end{array}$ & $\begin{array}{l}\mathrm{CC} \\
\text { /NR }\end{array}$ & $\begin{array}{l}726 / 1452 / 75.6 \% \\
/ 70.9 y / \\
\text { control:23.1; case: } \\
21.5\end{array}$ & $\begin{array}{l}\text { Diet } \\
/ \beta \text {-carotene }\end{array}$ & $\begin{array}{l}\mathrm{FFQ} / \beta-\text { Carotene } \\
\text { male:Q1:1882; } \\
\text { Q4: 5954; } \\
\text { female:Q1:1622; Q4: } \\
6281\end{array}$ & $\begin{array}{l}\text { Hip fracture } \\
\text { /Medical records }\end{array}$ & $\begin{array}{l}\text { Age, sex, drugs, BMI, } \\
\text { education, occupation, } \\
\text { household income, } \\
\text { family history, smoking, } \\
\text { alcohol drinking, Ca } \\
\text { and multivitamin } \\
\text { supplementation, physical } \\
\text { activity, intake of energy } \\
\text { and selected nutrients. }\end{array}$ & 7 \\
\hline $\begin{array}{l}\text { Zhang }^{(16)} \\
\text { /2005 } \\
\text { /US }\end{array}$ & $\begin{array}{l}\mathrm{CC} \\
\text { /NR }\end{array}$ & $\begin{array}{l}835 / 1826 / 78.5 \% \\
175.8 \mathrm{y} / \text { control: } \\
26.4 ; \text { case: } 24.5\end{array}$ & $\begin{array}{l}\text { Diet } \\
/ \beta \text {-carotene }\end{array}$ & $\begin{array}{l}\text { FFQ/ } \beta \text {-Carotene } \\
\text { Q1: } 1.8 ; \text { Q5:12.2 }\end{array}$ & $\begin{array}{l}\text { Hip fracture } \\
\text { /Medical records }\end{array}$ & $\begin{array}{l}\text { Age, sex, BMI, physical } \\
\text { activity, energy intake, } \\
\text { protein, caffeine and } \\
\text { alcohol, calcium and } \\
\text { vitamin D intakes. }\end{array}$ & 7 \\
\hline $\begin{array}{l}\text { Ambrosini(22) } \\
/ 2014 \\
\text { /Australia }\end{array}$ & $\begin{array}{l}\text { Prospective } \\
/ 7.0 \mathrm{y}\end{array}$ & $\begin{array}{l}\text { 123/929/ } \\
33.6 \% / 50.8 \mathrm{y} / \\
\text { control: } 28.1 \text {; case: } \\
27.4\end{array}$ & $\begin{array}{l}\text { Plasma } \\
\text { /carotene }\end{array}$ & $\begin{array}{l}\text { HPLC/carotene } \\
\text { T1: } 0.1-0.6 ; \mathrm{T} 3: \\
1.2-16.7\end{array}$ & $\begin{array}{l}\text { Any fracture/ } \\
\text { Self-report }\end{array}$ & $\begin{array}{l}\text { Sex, age, medications, } \\
\text { previous fracture, smoking } \\
\text { status }\end{array}$ & 7 \\
\hline $\begin{array}{l}\text { Barker }^{(25)} \\
/ 2005 \\
\text { /British }\end{array}$ & $\begin{array}{l}\mathrm{NCC} \\
/ 3.7 \mathrm{y}\end{array}$ & $\begin{array}{l}312 / 1246 / 100 \% \\
/ 80 \mathrm{y} / \mathrm{NR}\end{array}$ & $\begin{array}{l}\text { Serum } \\
/ \beta \text {-carotene }\end{array}$ & $\begin{array}{l}\text { HPLC/ } \beta \text {-Carotene } \\
\text { NR }\end{array}$ & $\begin{array}{l}\text { Hip fracture and } \\
\text { any fracture/ } \\
\text { Medical records }\end{array}$ & $\begin{array}{l}\text { Age, serum } 25(\mathrm{OH}) \mathrm{D} \text {, } \\
\beta \mathrm{CTX} \text {, bone ALP, total } \\
\text { hip BMD, weight, height, } \\
\text { smoking, exercise, milk } \\
\text { consumption }\end{array}$ & 7 \\
\hline
\end{tabular}

BMI: Body Mass Index; CA: carotenoids; FFQ: Food Frequency Questionnaire; HRT: Hormone Replace Therapy; CC: Case-Control study; NR: Not Reported; NCC: Nested Case-Control; HPLC: High-performance liquid chromatography; $\beta$-CTX: $\beta$ Crosslaps; ALP: Alkaline Phosphatase; BMD: Bone Mineral Density.

$(\mathrm{OR}=0.57,95 \% \mathrm{CI}: 0.40,0.81)$ or subjects aged over 60 years $(\mathrm{OR}=0.57,95 \% \mathrm{CI}: 0.40,0.81)$, or subjects with BMI $\leq 25 \mathrm{~kg} / \mathrm{m}^{2}(\mathrm{OR}=0.62,95 \%$ CI: $0.40,0.96$, $P=0.03$ ), or Asians (OR $=0.62,95 \%$ CI: $0.40,0.96$, $P=0.03)$, while further meta-regression analysis showed that the study characteristics of gender, age, BMI and location did not affect our results. (Table 2).

\section{Circulating carotene and any fracture risk}

There was no study concerning on the association between total circulating carotenoids and fracture risk. Only 2 studies prospectively assessed the relationship between circulating carotene levels and risk of any fracture; the pooled OR for high versus low carotene levels was 0.83 (95\% CI: $0.59,1.17)$.

\section{Sensitivity analysis}

Results of sensitivity analyses conducted by omitting one study at each time using a random-effects model showed that the combined results for dietary intake of total carotenoids and $\alpha$-carotene were sensitive to individual study. Dai et al's study focused on female subjects affected the association between dietary total carotenoids, $\alpha$-carotene and hip fracture risk, and the 
summary OR was 0.60 (95\% CI: $0.45,0.80)$ for total carotenoids and 0.65 (95\% CI: $0.50,0.85)$ for $\alpha$-carotene respectively when deleted this data set.

\section{Publication bias}

The Egger's tests did not indicate significant publication bias in the meta-analyses for dietary total carotenoids, $\alpha$-carotene, $\beta$-carotene, $\beta$-cryptoxanthin, lycopene, or Lutein/zeaxanthin $(P=0.16 ; P=0.36 ; P=0.10$; $P=0.49 ; P=0.14 ; P=0.60)$.

\section{DISCUSSION}

Based on the limited evidence from observational studies, our meta-analysis supported the hypothesis that higher dietary intake of total carotenoids or $\beta$-carotene might be potentially associated with a low risk of hip fracture, although an obvious heterogeneity was observed.

The mechanisms that carotenoids decreased hip fracture risk might be multi-factors, one was its antioxidant property [28], combining with its anti-catabolic and proanabolic activities, which could suppress osteoclast

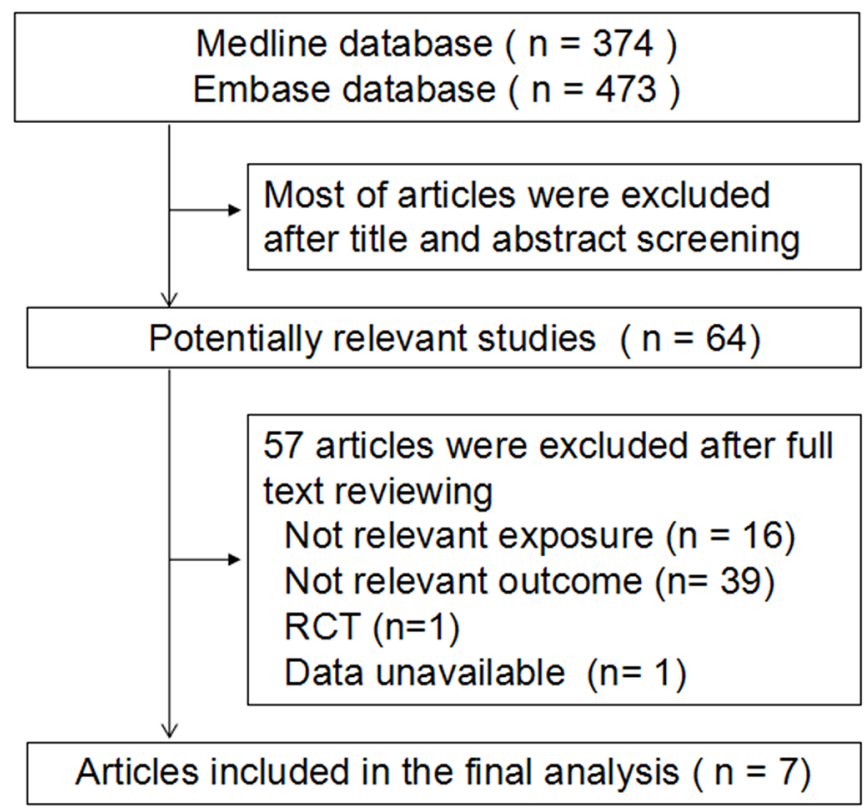

Figure 1: Flow chart of literature search.

\begin{tabular}{|c|c|c|}
\hline Study ID & $\mathrm{ES}(95 \% \mathrm{Cl})$ & Weight $\%$ \\
\hline \multicolumn{3}{|l|}{ Female } \\
\hline Dai(F),2014 & $0.95(0.79,1.15)$ & 42.91 \\
\hline Sahni(F),2009 & $0.56(0.30,1.01)$ & 19.40 \\
\hline Subtotal $(\mathrm{I}$-squared $=62.4 \%, p=0.103)$ & $0.79(0.48,1.30)$ & 62.31 \\
\hline \multicolumn{3}{|l|}{ Male } \\
\hline Dai(M),2014 & $0.63(0.45,0.88)$ & 33.50 \\
\hline Sahni(M),2009 & $0.34(0.07,1.74)$ & 4.18 \\
\hline Subtotal $(I-$ squared $=0.0 \%, p=0.461)$ & $0.61(0.44,0.85)$ & 37.69 \\
\hline Overall $(\mathrm{I}$-squared $=59.4 \%, p=0.061)$ & $0.72(0.51,1.01)$ & 100.00 \\
\hline NOTE: Weights are from random effects analysis & & \\
\hline
\end{tabular}

Figure 2: Association of total dietary carotenoids and hip fracture risk. 
Table 2: Effects of study characteristics on the association between dietary $\beta$-carotene and hip fracture risk

\begin{tabular}{|c|c|c|c|}
\hline Group & No. of studies & OR (95\% CI) & $\boldsymbol{P}_{\text {interaction }}$ \\
\hline All & 8 & $0.72(0.54,0.95)$ & \\
\hline Study design & & & 0.21 \\
\hline Prospective & 5 & $0.84(0.62,1.14)$ & \\
\hline Case-control & 3 & $0.55(0.34,0.89)$ & \\
\hline Gender & & & 0.22 \\
\hline Female & 5 & $0.80(0.58,1.11)$ & \\
\hline Male & 3 & $0.57(0.40,0.81)$ & \\
\hline Age (years) & & & 0.11 \\
\hline$<60$ & 3 & $0.91(0.66,1.27)$ & \\
\hline$\geq 60$ & 5 & $0.57(0.40,0.81)$ & \\
\hline BMI $\left(\mathrm{kg} / \mathrm{m}^{2}\right)$ & & & 0.40 \\
\hline$\leq 25$ & 4 & $0.62(0.40,0.96)$ & \\
\hline$>25$ & 4 & $0.85(0.57,1.26)$ & \\
\hline Location & & & 0.40 \\
\hline Asia & 4 & $0.62(0.40,0.96)$ & \\
\hline United States & 4 & $0.85(0.57,1.26)$ & \\
\hline
\end{tabular}

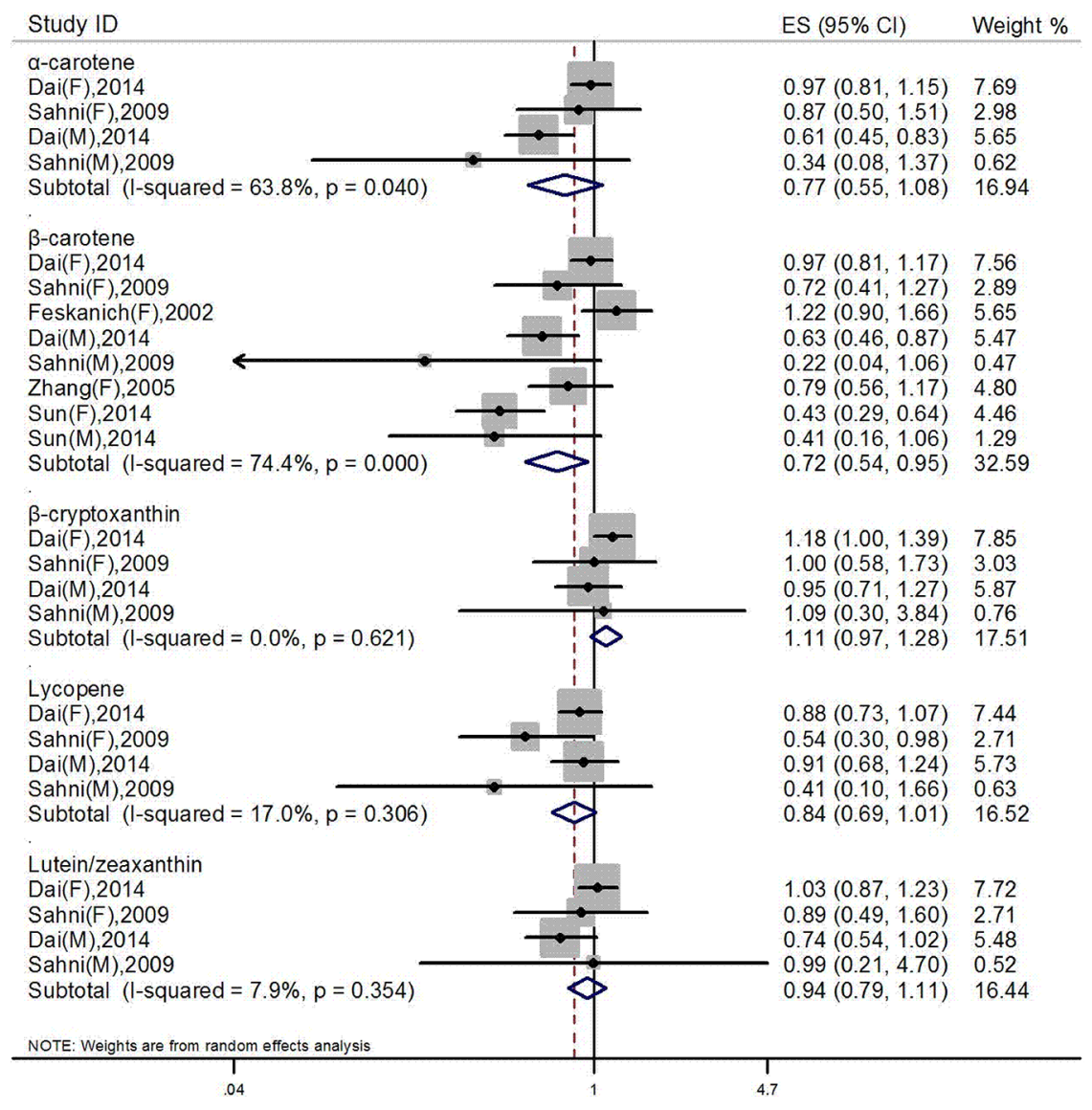

Figure 3: Pooled analysis between dietary special carotenoids and hip fracture risk. 
differentiation, promote osteoblast mineralization and stimulate alkaline phosphatase activity of osteoblasts $[13,29,30]$, on the other hand, carotenoids were the index of fruit and vegetable intake, whose beneficial role in decreasing fracture risk also had been widely proved, this support the beneficial role of dietary total carotenoids and $\beta$-carotene in decreased hip fracture risk.

Meanwhile, sex hormones regulated the biological effects of carotenoids, testosterone could increase the uptake and biological availability of carotenoids [31], the decreased level of testosterone and the loss of the estrogen function increased the risk of fracture. In our present study, the association of dietary intake of $\beta$-carotene with decreased fracture risk for men might be the synergistic effects of testosterone and the antioxidant property of $\beta$-carotene, while for postmenopausal women, the effect of oxidative stress on bone health may be less critical than estrogen level. Older people conserved higher susceptibility to fracture as aging resulted in serious bone loss [2], continually decreased level of estrogen and testosterone also increased hip fracture risk, thus, the positive association of dietary $\beta$-carotene intake with bone health might be more pronounced for those subjects who were at higher risk of fracture.

Previous research showed that BMI $<20 \mathrm{~kg} / \mathrm{m}^{2}$ is an independent risk factor of fracture [32], as low BMI usually encountered increased oxidative damage [33], while a higher $\mathrm{BMI}$ is regarded as a protective factor against hip fractures for the greater weight bearing in the loading bone sites [34], and the increased endogenous estrogen produced in adipose tissues for postmenopausal women [35]. In our present study, $\beta$-carotene intake was associated with decreased hip fracture risk for subjects with $\mathrm{BMI}<25 \mathrm{~kg} / \mathrm{m}^{2}$, this might be explained by the antioxidant property of carotenoids, on the other hand, subjects with lower BMI had less adipose tissue to store carotenoids, and the effects of carotenoids could be more direct.

Population came from different geographic area shared different genetic background, different dietary habit and lifestyle, which might result in the difference in the intake of carotenoids. Except the fact that Asian population have relatively lower rates of hip fracture [36] and shorter hip axis length [37], the significant association of $\beta$-carotene intake with decreased hip fracture risk for Asians might be the higher intake of vegetables and fruits, which was the main source of carotenoids in Asia [23], and their beneficial effect on fractures had been wildly testified $[13,15,18,27,38]$. Meanwhile, this also could explain the positive association of $\beta$-carotene with decreased hip fracture for subjects with BMI $<25 \mathrm{~kg} / \mathrm{m}^{2}$, as those subjects were all Asians.

Although there had many factors affected the absorption and tissue distribution of dietary carotenoids, blood is always the main tissue for carotenoids distribution [39]. Results from carefully controlled human intervention trials also testified the positive association between circulating carotenoids concentrations and dietary intake $[39,40]$, while the summary results of circulating carotene and fracture risk was inconsistent with the role of dietary carotene intake. The relatively small number of sample, measurement error or misclassification of exposure in assessing dietary carotenoids intake from a dietary questionnaire could result in the discrepancy between dietary and circulating level of carotenoids [41], on the other hand, the effects of carotenoids on fracture might be related to the subtype of fracture.

Our meta-analysis has limitations. First, there were not sufficient studies included, which attenuated the statistical power to detect the minor difference, limited our further dose-response meta-analysis, and this was also the common reason of heterogeneity. Second, all the included studies did not share the uniform exposure category and reference category of risk estimates, and we extracted the pooled risk estimates for the highest $v s$. the lowest category regardless of their cutoffs. Third, there might exist misclassification of dietary carotenoids intake and fracture assessment. Except one prospective study used repeated measurements of diet and supplement use during follow-up [26], others only used the baseline dietary data to calculate dietary carotenoids intake, and did not adjust for secular changes in diet during the follow-up period, the estimated intake levels might not reflect the actual amount of dietary carotenoids intake. Self-reported fractures might induce misclassification, however, Ivers's study regarded self-report fracture as a reasonable and accurate method for ascertaining the events of fractures in older adults during a long follow-up period [42]. Fourth, observational studies were not powerful to make a casual relationship, and for case-control studies, recall bias and selection bias were common shortcomings. Finally, there existed other residual confounders, such as vitamin D levels and hormone therapy for women.

Our meta-analysis based on 7 observational studies found that dietary intake of total carotenoids and $\beta$-carotene conserved the potentiality of decreased hip fracture risk, especially the negative association between dietary $\beta$-carotene intake and hip fracture risk for males or subjects aged over $60 \mathrm{y}$ or overweighted or Asians. With the increase of the elderly population, prevention of bone loss and associated fracture is becoming more important, our present data might be useful to provide dietary suggestions for people who are at higher risk of bone loss or fracture. Of course, large-scale prospective cohort studies and randomized controlled trials are need to be verified our results in further.

\section{MATERIALS AND METHODS}

\section{Literature search}

We searched articles aimed to evaluate the association between circulating or dietary carotenoids and 
fracture risk published throughout May 31th, 2016 from MEDLINE and EMBASE databases. We searched the terms of "carotenoids", "carotene", "lycopene", "tomato", " $\beta$-cryptoxanthin", "lutein", "zeaxanthin", and "vegetable and fruit" on MeSH term or in the Title/Abstract of articles; and then we searched "BMD", "osteoporotic fractures", "osteoporosis", and "fracture" on MeSH term or in the Title/Abstract of articles. And then we combined the 2 search results by using OR. All searches were limited to for human. Additionally, we manually searched relevant articles by screening the bibliography of selected articles, relevant reviews, and meta-analyses.

\section{Study selection}

The inclusion criteria were listed as follows: (1) prospective, case-control, or cross-sectional study; (2) the exposure of interest was dietary or circulating carotenoids; (3) the outcome was prevalence or first incidence of fracture; (4) providing the estimation of odds ratio (OR) or relative risk ( $\mathrm{RR}$ ) and its corresponding $95 \%$ confidence interval (CI) or standard error of estimations, or reporting the data to calculate these values; (5) adult participants.

\section{Data extraction}

The following information was extracted by two authors (Jiuhong XU and Chunli SONG) independently. Extracted study characteristics were as follows: last name of the first author, publication year, study location, number of cases/participants, age, sex, BMI, range of the carotenoids, method to determine the levels of the circulating/ diet carotenoids, OR or RR estimates and $95 \%$ CIs for each category of carotenoids, and variables adjusted for in the analysis models. If a study provided multiple risk estimates for several subtypes of carotenoids or for both sexes, the risk estimates were regarded as different reports only when they were divided into different subgroups. If the study calculated $\mathrm{RR} / \mathrm{OR}$ according to the percentile categories of the carotenoids levels, the risk estimate compared highest with the lowest category was extracted. If two or more risk estimates adjusted for different confounders were reported in one study, the RRs or ORs based on the full model were selected. We also tried to contact with corresponding authors of several studies for additional data.

\section{Assessment of the study quality}

The quality of the selected studies was assessed by using the Newcastle-Ottawa scale (NOS) [43]. The study was defined as having a high quality if the total score was no less than 6.

\section{Statistical methods}

To assess the association between carotenoids and fracture risk, we calculated the pooled risk estimates and their 95\% CIs using a random-effects model. OR was an approximate estimation for $\mathrm{RR}$, because hip fracture is relatively rare. Therefore, we combined OR from case-control studies and RR from prospective studies in this meta-analysis. We performed $Q$-test and calculated $\mathrm{I}^{2}$ statistic to examine the between-study heterogeneity. A $P$-value for $Q$-test of $<0.10$ or a $\mathrm{I}^{2}$ of $>50 \%$ indicated significant between-study heterogeneity [44]. Meta regression was conducted to investigate the source of heterogeneity. Subgroup analyses stratified by sex, age, BMI, different study location, and subtypes of carotenoids were conducted to investigate potential effect modifiers.

Sensitivity analyses were performed by deleting one study at each analysis to explore the source of heterogeneity and to testify the robustness of the pooled risk estimate. Potential publication bias was tested by using funnel plots, Begg's test, and Egger's test; and a $P<0.05$ indicated a significant publication bias [45]. All analyses were conducted by using STATA 11.0 (Stata Corp). A $P<0.05$ indicated statistical significance.

\section{ACKNOWLEDGMENTS AND FUNDING}

We appreciate Dr. Yiqing SONG's thoughtful comments and suggestions for statistical analysis and manuscript writing. We also thank Dr. Shivani Sahni's help for providing original data.

This work was supported by grants from the National Natural Science Foundation of China [No_81372980, 81673150, 81001185] and the Priority Academic Program Development of Jiangsu Higher Education Institutions (PAPD).

\section{CONFLICTS OF INTEREST}

The author(s) declare no competing financial interests.

\section{REFERENCE}

1. Christodoulou C, Cooper C. What is osteoporosis? Postgrad Med J. 2003; 79:133-138.

2. Weitzmann MN, Pacifici R. Estrogen deficiency and bone loss: an inflammatory tale. J Clin Invest. 2006; 116:1186-1194.

3. Garrett IR, Boyce BF, Oreffo RO, Bonewald L, Poser J, Mundy GR. Oxygen-derived free radicals stimulate osteoclastic bone resorption in rodent bone in vitro and in vivo. J Clin Invest. 1990; 85: 632-639.

4. Lee NK, Choi YG, Baik JY, Han SY, Jeong DW, Bae YS, Kim N, Lee SY. A crucial role for reactive oxygen species 
in RANKL-induced osteoclast differentiation. Blood. 2005; 106:852-859.

5. Jilka RL, Weinstein RS, Parfitt AM, Manolagas SC. Quantifying osteoblast and osteocyte apoptosis: challenges and rewards. J Bone Miner Res. 2007; 22:1492-1501.

6. Mody N, Parhami F, Sarafian TA, Demer LL. Oxidative stress modulates osteoblastic differentiation of vascular and bone cells. Free Radic Biol Med. 2001; 31:509-519.

7. Yalin S, Bagis S, Polat G, Dogruer N, Cenk Aksit S, Hatungil R, Erdogan C. Is there a role of free oxygen radicals in primary male osteoporosis? Clin Exp Rheumatol. 2005; 23:689-692.

8. Law MR, Hackshaw AK. A meta-analysis of cigarette smoking, bone mineral density and risk of hip fracture: recognition of a major effect. BMJ. 1997; 315:841-846.

9. Basu S, Michaelsson K, Olofsson H, Johansson S, Melhus H. Association between oxidative stress and bone mineral density. Biochem Biophys Res Commun. 2001; 288:275-279.

10. Maggio D, Barabani M, Pierandrei M, Polidori MC, Catani M, Mecocci P, Senin U, Pacifici R, Cherubini A. Marked decrease in plasma antioxidants in aged osteoporotic women: results of a cross-sectional study. J Clin Endocrinol Metab. 2003; 88:1523-1527.

11. Rock CL, Jacob RA, Bowen PE. Update on the biological characteristics of the antioxidant micronutrients: vitamin C, vitamin E, and the carotenoids. J Am Diet Assoc. 1996; 96: 693-702; quiz 3-4.

12. Rao LG, Krishnadev N, Banasikowska K, Rao AV. Lycopene I- effect on osteoclasts: lycopene inhibits basal and parathyroid hormone-stimulated osteoclast formation and mineral resorption mediated by reactive oxygen species in rat bone marrow cultures. J Med Food. 2003; 6:69-78.

13. Kim L, Rao AV, Rao LG. Lycopene II - effect on osteoblasts: the carotenoid lycopene stimulates cell proliferation and alkaline phosphatase activity of SaOS-2 cells. J Med Food. 2003; 6:79-86.

14. Yamaguchi M, Uchiyama S. Effect of carotenoid on calcium content and alkaline phosphatase activity in rat femoral tissues in vitro: the unique anabolic effect of betacryptoxanthin. Biol Pharm Bull. 2003; 26:1188-1191.

15. Sahni S, Hannan MT, Blumberg J, Cupples LA, Kiel DP, Tucker KL. Protective Effect of Total Carotenoid and Lycopene Intake on the Risk of Hip Fracture: A 17-Year Follow-Up From the Framingham Osteoporosis Study. Journal of Bone and Mineral Research. 2009; 24:1086-1094.

16. Zhang J. Antioxidant Intake and Risk of Osteoporotic Hip Fracture in Utah: An Effect Modified by Smoking Status. American Journal of Epidemiology. 2006; 163:9-17.

17. Melhus H, Michaelsson K, Holmberg L, Wolk A, Ljunghall S. Smoking, antioxidant vitamins, and the risk of hip fracture. J Bone Miner Res. 1999; 14:129-135.

18. Maggio D, Polidori MC, Barabani M, Tufi A, Ruggiero C, Cecchetti R, Aisa MC, Stahl W, Cherubini A. Low levels of carotenoids and retinol in involutional osteoporosis. Bone. 2006; 38:244-248.

19. Wattanapenpaiboon N, Lukito W, Wahlqvist ML, Strauss BJ. Dietary carotenoid intake as a predictor of bone mineral density. Asia Pac J Clin Nutr. 2003; 12:467-473.

20. Yang Z, Zhang Z, Penniston KL, Binkley N, Tanumihardjo SA. Serum carotenoid concentrations in postmenopausal women from the United States with and without osteoporosis. Int J Vitam Nutr Res. 2008; 78:105-111.

21. Sahni S, Hannan MT, Blumberg J, Cupples LA, Kiel DP, Tucker KL. Inverse association of carotenoid intakes with 4-y change in bone mineral density in elderly men and women: the Framingham Osteoporosis Study. Am J Clin Nutr. 2009; 89:416-424.

22. Ambrosini GL, Alfonso $\mathrm{H}$, Reid A, Mackerras D, Bremner AP, Beilby J, Olsen NJ, Musk AW, de Klerk NH. Plasma retinol and total carotenes and fracture risk after long-term supplementation with high doses of retinol. Nutrition. 2014; 30:551-556.

23. Dai Z, Wang R, Ang LW, Low YL, Yuan JM, Koh WP. Protective effects of dietary carotenoids on risk of hip fracture in men: The Singapore Chinese health study. Journal of Bone and Mineral Research. 2014; 29:408-417.

24. Mackinnon ES, Rao AV, Rao LG. Dietary restriction of lycopene for a period of one month resulted in significantly increased biomarkers of oxidative stress and bone resorption in postmenopausal women. J Nutr Health Aging. 2011; 15: 33-138.

25. Barker ME, McCloskey E, Saha S, Gossiel F, Charlesworth D, Powers HJ, Blumsohn A. Serum Retinoids and $\beta$-Carotene as Predictors of Hip and Other Fractures in Elderly Women. Journal of Bone and Mineral Research. 2005; 20:913-920.

26. Feskanich D, Singh V, Willett WC, Colditz GA. Vitamin A intake and hip fractures among postmenopausal women. JAMA. 2002; 287:47-54.

27. Sun LL, Li BL, Xie HL, Fan F, Yu WZ, Wu BH, Xue WQ, Chen YM. Associations between the dietary intake of antioxidant nutrients and the risk of hip fracture in elderly Chinese: a case-control study. Br J Nutr. 2014; 112: 1706-1714.

28. Wauquier F, Leotoing L, Coxam V, Guicheux J, Wittrant Y. Oxidative stress in bone remodelling and disease. Trends Mol Med. 2009; 15:468-477.

29. Park CK, Ishimi Y, Ohmura M, Yamaguchi M, Ikegami S. Vitamin A and carotenoids stimulate differentiation of mouse osteoblastic cells. J Nutr Sci Vitaminol (Tokyo). 1997; 43:281-296.

30. Uchiyama S, Yamaguchi M. beta-cryptoxanthin stimulates cell differentiation and mineralization in osteoblastic MC3T3-E1 cells. J Cell Biochem. 2005; 95:1224-1234.

31. Vinkler M, Albrecht T. Carotenoid maintenance handicap and the physiology of carotenoid-based signalisation of health. Naturwissenschaften. 2010; 97:19-28. 
32. De Laet C, Kanis JA, Oden A, Johanson H, Johnell O, Delmas P, Eisman JA, Kroger H, Fujiwara S, Garnero P, McCloskey EV, Mellstrom D, Melton LJ, et al. Body mass index as a predictor of fracture risk: a meta-analysis. Osteoporos Int. 2005; 16:1330-1338.

33. Djordjevic VB. Free radicals in cell biology. Int Rev Cytol. 2004; 237:57-89.

34. Dawson-Hughes B, Shipp C, Sadowski L, Dallal G. Bone density of the radius, spine, and hip in relation to percent of ideal body weight in postmenopausal women. Calcif Tissue Int. 1987; 40:310-314.

35. Kuller LH, Gutai JP, Meilahn E, Matthews KA, Plantinga P. Relationship of endogenous sex steroid hormones to lipids and apoproteins in postmenopausal women. Arteriosclerosis. 1990; 10: 1058-1066.

36. Xu L, Lu A, Zhao X, Chen X, Cummings SR. Very low rates of hip fracture in Beijing, People's Republic of China the Beijing Osteoporosis Project. Am J Epidemiol. 1996; 144:901-907.

37. Cummings SR, Cauley JA, Palermo L, Ross PD, Wasnich RD, Black D, Faulkner KG. Racial differences in hip axis lengths might explain racial differences in rates of hip fracture. Study of Osteoporotic Fractures Research Group. Osteoporos Int. 1994; 4:226-269.

38. Sugiura M, Nakamura M, Ogawa K, Ikoma Y, Ando F, Shimokata H, Yano M. Dietary patterns of antioxidant vitamin and carotenoid intake associated with bone mineral density: findings from post-menopausal Japanese female subjects. Osteoporosis International. 2011; 22:143-152.

39. Moran NE, Erdman JW, Jr., Clinton SK. Complex interactions between dietary and genetic factors impact lycopene metabolism and distribution. Arch Biochem Biophys. 2013; 539:171-180.

40. Allen CM, Schwartz SJ, Craft NE, Giovannucci EL, De Groff VL, Clinton SK. Changes in plasma and oral mucosal lycopene isomer concentrations in healthy adults consuming standard servings of processed tomato products. Nutr Cancer. 2003; 47:48-56.

41. Sesso HD, Liu S, Gaziano JM, Buring JE. Dietary lycopene, tomato-based food products and cardiovascular disease in women. J Nutr. 2003; 133:2336-2341.

42. Ivers RQ, Cumming RG, Mitchell P, Peduto AJ. The accuracy of self-reported fractures in older people. J Clin Epidemiol. 2002; 55:452-457.

43. Hartling L, Milne A, Hamm MP, Vandermeer B, Ansari M, Tsertsvadze A, Dryden DM. Testing the Newcastle Ottawa Scale showed low reliability between individual reviewers. J Clin Epidemiol. 2013; 66:982-993.

44. DerSimonian R, Laird N. Meta-analysis in clinical trials. Control Clin Trials. 1986; 7:177-188.

45. Egger M, Davey Smith G, Schneider M, Minder C. Bias in meta-analysis detected by a simple, graphical test. BMJ. 1997; 315:629-634. 